\title{
Benthic diatom community structure and habitat preferences along an urban pollution gradient in the Monjolinho River, São Carlos, SP, Brazil
}

\author{
Estrutura da comunidade de diatomáceas bentônicas e preferências de habitat ao longo \\ de uma gradiente de poluição urbana no Rio do Monjolinho, São Carlos, SP, Brasil
}

\section{Taurai Bere}

Programa de Pós-Graduação em Ecologia e Recursos Naturais, Departamento de Ciências Biológicas, Universidade Federal de São Carlos - UFSCar, Rodovia Washington Luís, Km 235, SP-310, CEP 13565-905, São Carlos, SP, Brazil e-mail: taubere@yahoo.com

\begin{abstract}
Aims: The objective of this study was to assess the effects of substrate selection on benthic diatom community structure along an urban pollution gradient. Methods: Substrate assessment, diatom and water sampling was done four times, two times in September and October/08 and two times in May and June/09. Species substrate preference was determined using the Indval method. Benthic diatom community structure (species richness, diversity and equitability) in relation to pollution levels was also evaluated. Results: Species richness, diversity and equitability differed significantly among sampling sites, tending to be higher in relatively unpolluted (1,2, 3 and 7) compared to polluted sites $(5,6,7,8,9$ and 10$)$. Species richness, diversity and equitability did not differ significantly among substrates from the same sites though more species tended to prefer natural, especially vegetation, as indicated by their highest indicator values in this substrate. Conclusion: Substrate differences may affect benthic diatom communities growing on them. Benthic diatoms tend to prefer natural substrates, especially vegetation, compared to artificial substrates, because of the selective nature of the physical and chemical properties of artificial substrates.
\end{abstract}

Keywords: natural and artificial substrates, indicator species.

Resumo: Objetivo: O objetivo deste estudo foi avaliar os efeitos da seleçáo do substrato na estrutura das comunidades de diatomáceas bentônicas ao longo de uma gradiente de poluiçẫo urbana. Métodos: Avaliação de substrato, amostragem diatomáceas e de água foi feito quatro vezes, duas vezes em setembro e outubro/08 e duas vezes em maio e junho/09. Preferência de espécie ao substrato foi determinada através do método Indval. A estrutura da comunidade de diatomáceas bentônicas (riqueza de espécies, diversidade e equitabilidade) em relação aos níveis de poluição também foi avaliada. Resultados: A riqueza de espécies, diversidade e equitabilidade diferiram significativamente entre os locais de amostragem, tendendo a ser maiores nos pontos menos poluídos $(1,2,3$ e 7) quando comparados aos pontos poluídos $(5,6,7,8,9$ e 10). A riqueza, diversidade e equitabilidade não diferiram significativamente entre os substratos dos mesmos pontos de coleta, embora um maior numero de espécies preferiram substratos naturais, especialmente vegetação, conforme apontado pelos mais elevados valores indicadores nestes substratos. Conclusáo: Diferenças de substrato podem afetar as comunidades de diatomáceas bentônicas crescendo neles. Diatomáceas bentônicas tendem a preferir substratos naturais, especialmente vegetação, quando comparados aos substratos artificiais, devido ao caráter seletivo das propriedades físicas e químicas de substratos artificiais.

Palavras-chave: substratos naturais e artificiais, espécies indicadoras. 


\section{Introduction}

Diatoms are good indicators of environmental conditions in lotic systems. Round (1991) noted three features that have confused the use of diatoms in biological monitoring of lotic systems. These include: 1) an almost total lack of appreciation of microhabitats with their characteristic floras; 2) semantic problems in language, translation and writing in languages other than one's own; and 3) the excessive searching for and counting of numbers of cells (valves) of species, resulting in lengthy lists which are simply list of few abundant species confused by multitudes of causal species. The first feature bears special relevance to this study.

Species composition and abundance of benthic diatom communities sampled at the same site but from different substrates (e.g., sand, rock surface, submerged or emergent macrophytes) often differ substantially because species are better adapted to one substrate than other substrates (Round, 1991; Patrick and Hendrickson, 1993; Potapova and Charles, 2005; Fisher and Dunbar, 2007). Substrate differences can potentially affects responses of diatom assemblages to stress associated with human activities and may interfere with water quality assessments based on knowledge of these responses. This is particularly important in large-scale water quality assessment surveys that are carried out in diverse landscapes where a single substrate may not be present at all sampling sites (Potapova and Charles, 2005). Therefore, a careful consideration of these factors during sample collection and subsequent data interpretation is necessary as ignoring them is likely to lead to biased results.

Previous diatom-based water quality assessment studies offers contrasting results with others emphasizing the importance of substrates (e.g., Lowe and Pan, 1996; Kelly et al., 1998) while others have not found significant between-substrate differences in diatom assemblages possibly because the effects of other environmental variables was overriding (Jüttner et al., 1996; Rott et al., 1998; Kitner and Poulícková, 2003; Soinine and Eloranta, 2004). More work is therefore called for to shade more light on the importance of substrates in diatom-based water quality assessment.

The objective of this study was to assess the effects of substrate selection on benthic diatom community structure along an urban pollution gradient using the Indicator Value (Indval) method. The novelty of this approach lies in the way it combines a species' relative abundance to its relative frequency of occurrence in the various groups of samples. Indicator species are defined as the most characteristic species of substrate, found mostly in a single substrate and present in the majority of the sites where that substrate is present. This duality, which is of ecological interest, is rarely completely exploited in most of the methods designed to assess the effects of substrate on benthic diatom communities in lotic systems.

\section{Methods}

\subsection{Study area}

The area under study is shown in Figure 1. Headwaters of Monjolinho and the tributaries studied fall within mainly agricultural area. From agricultural area, the streams run through urban area of the city of São Carlos, which covers a total area of $1143.9 \mathrm{~km}^{2}$. The area is characterized by undulating terrain. The average annual temperature is around $19.5^{\circ} \mathrm{C}$, with mean monthly maximum of around $21.9^{\circ} \mathrm{C}$ recorded in January and February and the mean monthly minimum of around $15.9^{\circ} \mathrm{C}$ recorded in July.

In 2008, the population of Sáo Carlos was estimated at 218, 080 inhabitants by Instituto Brasileiro de Geografia e Estatística (IBGE). Now, the expansion of the city does not meet the technical standards that go with it in terms of sewage treatment, collection of garbage, urban drainage and so on. Streams in the study area, therefore, receive untreated or semi-treated effluent from various domestic and industrial sources as well as other diffuse sources as they pass through the city. This disorderly growth of the city resulted in stream health deterioration, loss of the remaining primary vegetation and eutrophication among other problems.

Ten sites were established along Monjolinho River and its tributaries: four sites $(1,2,3$ and 7) in the relatively less impacted agricultural and forested headwaters to act as reference sites; 3 sites (4, 5 and 6$)$ in the moderately polluted urban area; and 3 sites (8,9 and 10) in highly polluted downstream area after the urban area (Figure 1). These three site categories roughly compares with classification of these sites based on physical and chemical variables (Table 1). The rational for choosing the sampling sites was to obtain a pollution gradient of all the stream systems from relatively unpolluted agricultural headwaters to highly polluted urban downstream sites.

\subsection{Data collection}

Substrate assessment, diatom and water sampling was done during summer season when 


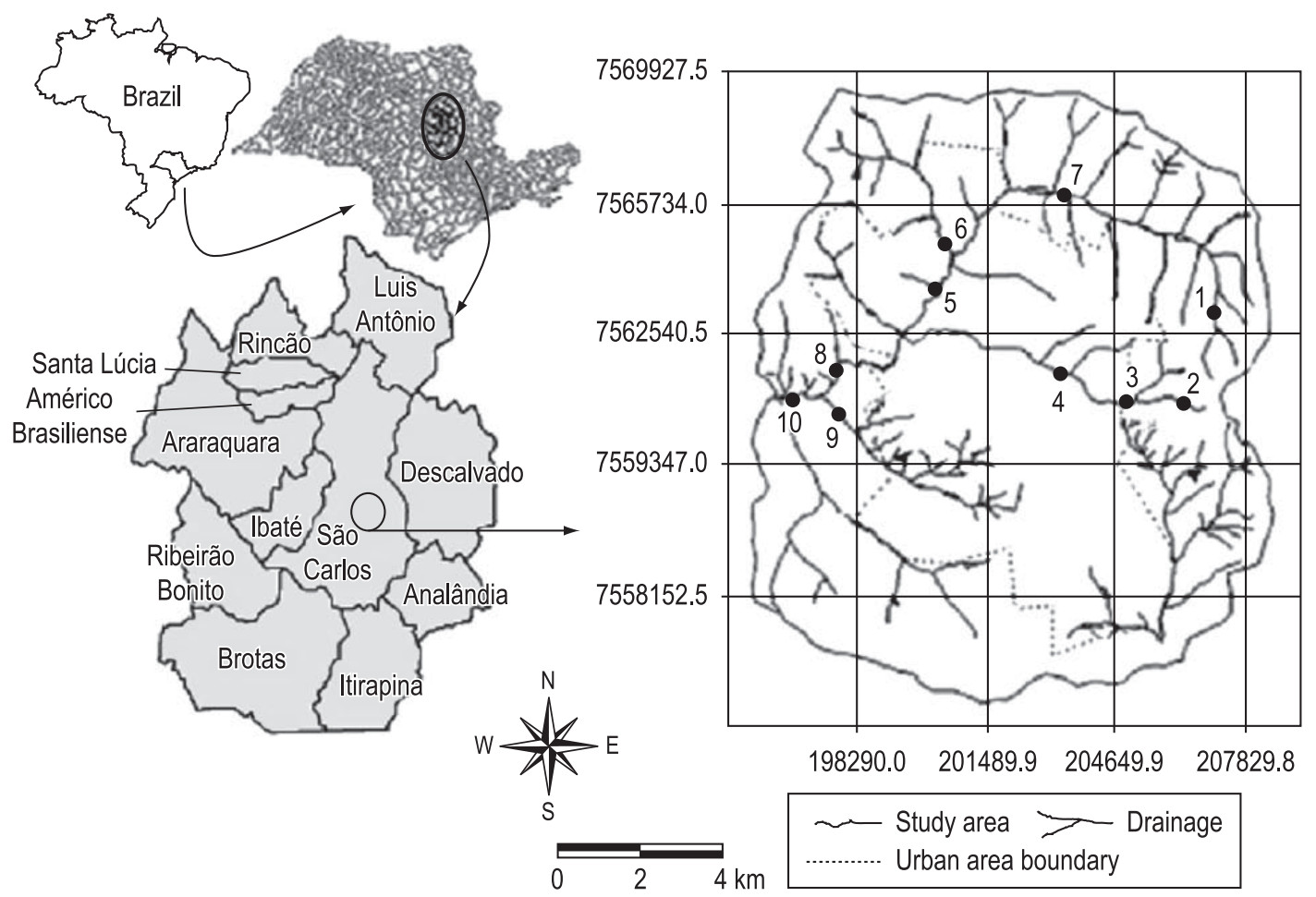

Figure 1. The location of the sampling sites in the study area.

Table 1. The mean $(n=4)$ values of physical and chemical variables measured at 10 sites during four sampling periods.

\begin{tabular}{|c|c|c|c|c|c|c|c|c|c|c|}
\hline Site & 1 & 2 & 3 & 7 & 4 & 5 & 6 & 8 & 9 & 10 \\
\hline Temperature ${ }^{\circ} \mathrm{C}$ & $18.3 \pm 1.1$ & $20.9 \pm 1.6$ & $20.6 \pm 1.7$ & $24.0 \pm 2.6$ & $21.2 \pm 1.7$ & $21.2 \pm 1.1$ & $20.4 \pm 1.5$ & $24.8 \pm 3.0$ & $23.0 \pm 1.9$ & $21.3 \pm 2.2$ \\
\hline Altitude (m) & 761 & 837 & 831 & 774 & 794 & 745 & 761 & 724 & 630 & 627 \\
\hline Canopy cover (\%) & 80 & 95 & 60 & 20 & 50 & 4 & 45 & 20 & 50 & 5 \\
\hline $\mathrm{BOD}_{5}\left(\mathrm{mg} \mathrm{L}^{-1}\right)$ & $0.9 \pm 0.2$ & $1.0 \pm 1.2$ & $2.6 \pm 0.2$ & $1.6 \pm 0.6$ & $6.9 \pm 0.2$ & $1.2 \pm 2.3$ & $7.2 \pm 1.1$ & $19.5 \pm 1.1$ & $24.5 \pm 1.2$ & $26.2 \pm 1.3$ \\
\hline $\mathrm{COD}\left(\mathrm{mg} \mathrm{L}^{-1}\right)$ & $3.7 \pm 0.8$ & $4.2 \pm 1.3$ & $12.3 \pm 4.2$ & $6.3 \pm 0.5$ & $83.3 \pm 14.5$ & $4.8 \pm 0.7$ & $11.7 \pm 1.5$ & $54.0 \pm 19.9$ & $103.0 \pm 3.2$ & $103.0 \pm 22.7$ \\
\hline $\mathrm{DO}\left(\mathrm{mg} \mathrm{L}^{-1}\right)$ & $7.3 \pm 2.3$ & $8.2 \pm 1.0$ & $7.6 \pm 0.6$ & $6.8 \pm 2.1$ & $6.9 \pm 1.0$ & $7.6 \pm 1.3$ & $7.2 \pm 1.5$ & $1.9 \pm 2.8$ & $2.1 \pm 1.0$ & $0.4 \pm 1.2$ \\
\hline $\begin{array}{l}\text { Conductivity } \\
\left(\mu \mathrm{Scm}^{-1}\right)\end{array}$ & $45.0 \pm 7.5$ & $20.0 \pm 10.5$ & $53.0 \pm 9.5$ & $28.0 \pm 7.7$ & $89.0 \pm 8.9$ & $103.0 \pm 6.4$ & $30.0 \pm 4.0$ & $715.0 \pm 22.3$ & $322.0 \pm 191.3$ & $283.0 \pm 201.7$ \\
\hline $\mathrm{pH}$ & $6.6 \pm 0.8$ & $6.4 \pm 1.0$ & $6.3 \pm 1.0$ & $6.7 \pm 0.6$ & $6.8 \pm 0.9$ & $7.2 \pm 0.4$ & $6.8 \pm 1.0$ & $7.2 \pm 0.5$ & $7.2 \pm 0.4$ & $7.1 \pm 0.4$ \\
\hline $\operatorname{TDS}\left(\mathrm{g} \mathrm{L}^{-1}\right)$ & $29.4 \pm 0.5$ & $13.4 \pm 1.2$ & $22.6 \pm 3.2$ & $18.1 \pm 1.4$ & $57.4 \pm 3.4$ & $66.5 \pm 2.9$ & $19.3 \pm 0.2$ & $457.8 \pm 27.1$ & $206.1 \pm 11.1$ & $182.0 \pm 34.1$ \\
\hline Turbidity(NTU) & 0 & 0 & 0 & 0 & 0 & 0 & 0 & 0.1 & 0.1 & 0.1 \\
\hline $\mathrm{TN}\left(\mathrm{mg} \mathrm{L}^{-1}\right)$ & $0.65 \pm 0.3$ & $0.18 \pm 0.3$ & $0.24 \pm 1.4$ & $1.72 \pm 0.5$ & $1.29 \pm 0.4$ & $1.41 \pm 0.5$ & $0.93 \pm 0.7$ & $38.32 \pm 8.3$ & $14.87 \pm 4.1$ & $10.17 \pm 2.9$ \\
\hline $\mathrm{TP}\left(\mathrm{mg} \mathrm{L}^{-1}\right)$ & $0.01 \pm 0.0$ & $0.01 \pm 0.0$ & $0.01 \pm 0.1$ & $0.03 \pm 0.0$ & $0.16 \pm 0.2$ & $0.06 \pm 0.1$ & $0.02 \pm 0.0$ & $2.97 \pm 1.0$ & $1.12 \pm 0.2$ & $0.75 \pm 0.2$ \\
\hline Mean depth (m) & $0.2 \pm 0.02$ & $0.3 \pm 0.08$ & $0.4 \pm 0.10$ & $0.2 \pm 0.05$ & $0.4 \pm 0.08$ & $0.3 \pm 0.05$ & $0.4 \pm 0.01$ & $0.5 \pm 0.07$ & $0.3 \pm 0.04$ & $0.3 \pm 0.01$ \\
\hline Velocity $\left(\mathrm{m} \mathrm{s}^{-1}\right)$ & $2.5 \pm 1.3$ & $2.8 \pm 1.4$ & $2.6 \pm 1.3$ & $2.23 \pm 1.1$ & $2.7 \pm 1.2$ & $1.4 \pm 0.6$ & $2.9 \pm 1.1$ & $3.5 \pm 1.8$ & $2.4 \pm 0.9$ & $2.34 \pm 1.0$ \\
\hline Silt-Clay (\%) & 95 & 95 & 10 & 30 & 15 & 10 & 50 & 5 & 10 & 10 \\
\hline Sand (\%) & 2 & 0 & 90 & 60 & 50 & 90 & 80 & 10 & 90 & 10 \\
\hline Gravel (\%) & 0 & 2 & 3 & 40 & 5 & 5 & 5 & 5 & 3 & 15 \\
\hline Cobble (\%) & 0 & 2 & 4 & 10 & 20 & 5 & 5 & 5 & 5 & 50 \\
\hline Boulders (\%) & 0 & 3 & 0 & 0 & 5 & 2 & 2 & 10 & 0 & 60 \\
\hline Silt-gravel (\%) & 95 & 97 & 95 & 85 & 80 & 83 & 85 & 35 & 95 & 40 \\
\hline Gravel-Cobble (\%) & 0 & 2 & 5 & 10 & 15 & 10 & 10 & 50 & 5 & 50 \\
\hline Cobble-Bolder (\%) & 0 & 1 & 0 & 5 & 10 & 7 & 5 & 60 & 0 & 70 \\
\hline Embeddedness & 0 & 0 & 1 & 2 & 3 & 1 & 1 & 5 & 1 & 4 \\
\hline
\end{tabular}


flow was stable. Four samples were collected, two in September and October/08 and two in May and June/09. Sampling was done during dry season to avoid variable effects of rainy season like great variations in water level and velocity, floods and inundations. These factors affect diatom development, especially growth rate and relative abundance of different species (Round, 1991; Biggs, 1990, 1995; Patrick and Hendrickson, 1993; Duong et al., 2006, 2007). All the physical and chemical characteristics that vary with time were measured during every sampling event.

At each site, dissolved oxygen (DO), electrical conductivity, temperature, $\mathrm{pH}$, concentration of total dissolved solids (TDS) and turbidity were measured using a Horiba U-23 and W-23XD Water Quality Meter (Horiba Ltd, Japan). Depth and current velocity were measured at each site with an FP 201 global flow probe (Global Water Instrumentation Inc. Alaska, USA). The percentage riparian vegetation cover was estimated at each site. Altitude was determined at each site using a GPS (Northport Systems, Inc. Toronto, Canada). The percentage embeddedness was also estimated along each stretch and rated on a $0-5$ scale following Platts et al., (1983).

The following physical substrate characteristics were visually estimated following USGS NAWQA protocol (Fitzpatrick et al., 1998): percentage of silt-clay size particles, sand size particles, gravel size particles, cobble size particles, boulder size particles; ratio of silt-gravel size particles, gravel-cobble size particles, and cobble-boulder size particles.

Water samples for total nitrogen (TN) and total phosphorus (TP) analysis were also collected at each site into acid-cleaned polythene containers (Valderrama, 1981). Water samples for biological oxygen demand $\left(\mathrm{BOD}_{5}\right)$ and chemical oxygen demand (COD) were also collected following APHA (1988).

Substrates present at each sampling site were classified into four categories; (1) stones - epilithic, (2) vegetation (submerged/emergent) - epiphytic, (3) sand - epipsammic and (4) silt/clay - epipelic, based on USGS NAWQA protocol (Fitzpatrick et al., 1998). At each site, epilithic, epiphytic, epipelic and epipsammic diatoms were sampled separately, avoiding mixing as much as possible.

Epilithic diatoms were sampled by brushing stones with a toothbrush. Prior to sampling, the stones were gently shaken in stream to remove any loosely attached sediments and non-epilithic diatoms. At least five pebble-to-cobble sized stones were randomly collected along each sampling stretch, brushed and the resulting diatom suspensions were pooled to form a single sample that was then put in a labelled plastic bottle. Epiphytic diatoms were sampled from various submerged macrophytes at each site depending on the availability of the macrophytes. The macrophyte's whole stalk comprising of stalk and leaves was carefully removed from the stream. Periphyton was then removed from the macrophytes by brushing with a toothbrush adding distilled water. The resulting diatom suspensions from all the submerged macrophytes sampled were pooled to form a single sample, which was then put in a labelled plastic bottle. Epipelic and epipsammic diatoms were sampled by pressing a Petri dish lid into the top layer of sand or silt/clay to a depth of 5-7 $\mathrm{mm}$ followed by sliding a spatula blade under the Petri dish to isolate the contents in the dish that were then gently brought to the surfaces. The contents were then emptied into a labelled container.

At each site, two bricks and four rough glass slides, as artificial substrate for algal attachment, were immersed in the water column, parallel to the current at a depth of 20 to $30 \mathrm{~cm}$ below the surface. The first batch of artificial substrates was placed at all sites in September 2008 and sampled in October 2008. The second batch was placed at all sites in May 2009 and sampled in June 2009. In all the cases, the artificial substrates were left for 4 weeks, which is the recommended colonization time of periphyton (Round, 1991; Descy and Coste, 1991; Kelly et al., 1998). The glass slides were placed on a metal rake that was secured by means of wire, pegs, and stones. On sampling, the artificial substrates were carefully brought to the surface and thoroughly rinsed with filtered river water. Biofilms were collected by brushing material with a toothbrush. The resulting suspensions from the replicates were pooled.

\subsection{Laboratory analysis}

The concentrations of TN and TP in the water samples were determined following Golterman et al., (1978) and Valderrama (1981) respectively. BOD and COD were determined following standard methods APHA (1988).

Sub-samples of the diatom suspensions were cleaned of organic material using wet combustion with concentrated sulphuric acid and mounted in Naphrax (Northern Biological supplies Ltd. UK. $\mathrm{RI}=1.74)$ following (Biggs and Kilroy 2000). Three replicate slides were prepared for each sample. 
A total of 250-600 valves per sample (depending on the abundance of diatoms) were identified and counted using the phase contrast light microscope (1000x) (Leica Microsystems, Wetzlar GmbH, Type - 020-519.503 LB30T, Germany). The mean and standard deviations of counting efficiencies of diatom communities calculated according to Pappas and Stoermer (1996) on different substrates were as follows: vegetation, $82.5 \pm 11.4 \%$; sand, $86.1 \pm 7.6 \%$; stones, $83.6 \pm 18.5 \%$; silt/clay, $82.9 \pm 14.2 \%$; bricks, $76.4 \pm 15.3 \%$ and glass, $78.0 \pm 17.1 \%$. The diatoms were identified to species level based on studies by Bourrelly (1981), Oliveira et al. (2001), Souza (2002), Lobo et al., (2002, 2004), Metzeltin et al., (2005), Bicudo and Menezes (2006), Salomoni et al. (2006), Metzeltin and Lange-Bertalot (2007), Delgado et al. (2007), Moura et al. (2007), Soares et al. (2007), Zalocar de Damitrovic et al. (2007) and Souza and Senna (2009). In all cases, identification of diatom specimens was based on acid-cleaned specimens. Fresh specimens were not used for identification hence no confirmation of the presence or absence of plastids was made.

\subsection{Statistical analysis}

Species richness $(\mathrm{S})$, Shannon's diversity $\left(\mathrm{H}^{\prime}\right)$ and equitability indices (E) calculated according to Shannon (1948) were used as measures of community structure. A nonparametric test, Kruskal-Wallis, analogous to analysis of variance, with Mann-Whitney pairwise comparisons and Bonferroni correction, was used to compare means of $\mathrm{S}, \mathrm{H}^{\prime}$ and $\mathrm{E}$ among substrates sampled and among the four sampling periods. This nonparametric method was chosen to avoid the distortion of the natural information resulting from powerful transformations, needed to compensate for the fact that normality rarely occurs in nature (Jongman et al., 1987). This test was also used to compare means of $S, \mathrm{H}^{\prime}$ and $\mathrm{E}$ among four natural and two artificial substrates sampled and to compare the means of these community attributes among three site categories described above. This test was also used to compare means of environmental variables among the sampling seasons and among the sampling site categories.

The IndVal method (Dufrêne and Legendre, 1997) was used to find indicator species and species assemblages characterizing different substrates. This method combines a species' relative abundance with its relative frequency of occurrence in the various substrates. Indicator species are defined as the most characteristic species of each substrate, found mostly in a single substrate and present in the majority of those substrates. Kruskal-Wallis, with MannWhitney pairwise comparisons and Bonferroni correction tests was used to compare indicator values of species on different substrates.

Kruskal-Wallis with Mann-Whitney pairwise comparisons and Bonferroni correction was performed using PAlaeontological STatistics (PAST) software version 1.95 (Hammer et al., 2009).

\section{Results}

\subsection{Physical and chemical variables}

The values of physical and chemical variables measured in the study area during the study period are shown in Table 1 . The water quality generally tended to deteriorate downstream as the streams pass through the urban area due to discharge of treated and untreated domestic and industrial effluent as well as other diffuse sources of pollution from the city. The $\mathrm{pH}$ increased slightly down the agricultural to urban gradient being slightly acidic at upstream sites and slightly alkaline/neutral at downstream sites. However, the difference in $\mathrm{pH}$ among the three site categories described above was not statistically significant (Kruskal-Wallis, $\mathrm{p}>0.05$ ). Temperature increased downstream, but as in the case of $\mathrm{pH}$, the increase was not significant (Kruskal-Wallis, $\mathrm{p}>0.05$ ). On the other hand, conductivity, $\mathrm{BOD}_{5}$, COD, TDS, turbidity, TN, TP and embeddedness increased significantly downstream (Kruskal-Wallis, $\mathrm{p}<0.05)$ while percentage of fine particles, DO and percentage riparian vegetation cover decreased significantly downstream (Kruskal-Wallis, $\mathrm{p}<0.05$ ). No significant difference was observed in means of environmental variables among the four sampling periods (Kruskal-Wallis, $\mathrm{p}>0.05$ ). This is expected since all sampling was confined to stable base flow period when variations in water chemistry are low compared to the rainy season. Therefore, a pooled data set, consisting of environmental variables sampled during four sampling periods was used to investigate the effects of substrate type on diatom communities and spatial trends in the composition of diatom communities.

\subsection{Community structure}

A total of 208 diatom species belonging to 63 genera that are distributed among the families Achnanthidiaceae, Achnanthaceae, Bacillariaceae, Eunotiaceae, Cymbellaceae, Gomphonemataceae, Fragilariaceae, Melosiraceae, 
Naviculaceae, Rhoicospheniaceae, Rhopalodiaceae and Surirellaceae were recorded in all the diatom samples collected. Of the 208 species observed, 45 species (Table 2, Figure 2) were considered the most dominant in the study area $(\geq 5 \%$ occurrence and present in at least 2 substrates from all sampling sites following Potapova and Charles $(2003,2005)$ and Doung et al. (2007). Twenty-four genera made up $88.6 \%$ of the overall diatom community. These were Nitzschia, Gomphonema, Eunotia, Pinnularia, Fragilaria, Rhoicosphenia, Aulacoseira, Nupela, Frustulia, Ulnaria ulna, Navicula, Achnanthidium, Sellaphora, Encyonema, Meridion, Cyclotella, Hantzschia, Amphora, Cymbopleura, Melosira, Neidium, Surirella, Psammothidium, and Achnanthes.

No significant differences (Kruskal-Wallis, p > 0.05) in $S, H^{\prime}$ and $E$ were observed among the four sampling periods. Therefore, a pooled data set, consisting of diatoms sampled during four sampling periods was used to investigate the effects of substrate type on diatom communities and spatial trends in the composition of diatom communities. Species richness, diversity and equitability did not differ significantly (Kruskal-Wallis, $\mathrm{p}>0.05$ ) among the six substrates sampled. However, these community attributes differed significantly (Kruskal-Wallis, $\mathrm{p}<0.05$ ) among the three sampling site categories, tending to be highest at upstream relatively unpolluted mainly agricultural and forest area reference sites and lowest at downstream highly polluted mainly urban sites (Table 3).

\subsection{Species distribution}

The most frequently occurring diatom species had a generally widespread distribution, occurring in almost all the substrates sampled. The upstream, relatively less impacted sites (1, 2, 3, and 7) were characterized by such species as Aulacoseira ambigua (Grunow) Simonsen, Aulacoseira granulata (Ehrenb) Simonsen and Cymbopleura naviculiformis (Auerswald) Krammer. On the other hand, downstream highly impacted sites were characterized by Gomphonema parvulum (Kützing) Cleve, Nitzschia palea (Kützing) Smith, Nupela praecipua (Reichardt) Reichardt, Rhoicosphenia abbreviata (Kützing) Grunow, Sellaphora pupula (Kützing) Mereschkowsky Fallacia monoculata (Hust) Mann and Luticola goeppertiana (Bleisch) Mann. Moderately impacted sites were dominated by Eunotia bilunaris (Ehrenberg) Mills, Fragilaria capucina Desmaziéres, Gomphonema angustatum

Table 2. The most frequently occurring diatom taxa with the highest indicator values (\%) in the different microhabitats sampled.

\begin{tabular}{|c|c|c|c|c|c|}
\hline Vegetation & Sand & Silt/clay & Stones & Glass & Bricks \\
\hline $\begin{array}{l}\text { Aulacoseira } \\
\text { agassizii } 43.9\end{array}$ & $\begin{array}{l}\text { Achnanthidium } \\
\text { biasolettianum } 41.2\end{array}$ & $\begin{array}{l}\text { Aulacoseira } \\
\text { distans } 44.8\end{array}$ & $\begin{array}{l}\text { Aulacoseira } \\
\text { ambigua } 39.7\end{array}$ & $\begin{array}{l}\text { Fallacia } \\
\text { monoculata } 49.5\end{array}$ & $\begin{array}{l}\text { Gomphonema } \\
\text { angustatum } 43.4\end{array}$ \\
\hline Diatoma hiemale 52.8 & $\begin{array}{l}\text { Achnanthidium } \\
\text { minutissimum } 36.6\end{array}$ & $\begin{array}{l}\text { Encyonema } \\
\text { silesiacum } 41.4\end{array}$ & $\begin{array}{l}\text { Cymbopleura } \\
\text { naviculiformis } 41.7\end{array}$ & Nitzschia palea 28.6 & $\begin{array}{l}\text { Luticola } \\
\text { geoppertiana } 30.0\end{array}$ \\
\hline Diatoma vulgare 47.2 & $\begin{array}{l}\text { Aulacoseira } \\
\text { alpigena } 39.7\end{array}$ & Eunotia intermedia 39.0 & \multicolumn{3}{|c|}{ Neidium ampliatum 31.7 Nupela praecipua 33.5} \\
\hline Eunotia bilunaris 71.3 & $\begin{array}{l}\text { Cyclotella } \\
\text { meneghiniana } 50.8\end{array}$ & Frustulia saxonica 28.0 & \multicolumn{3}{|c|}{ Stauroneis phoenicenteron 46.3} \\
\hline Eunotia papilio 69.5 & Eunotia pectinalis 29.4 & Frustulia vulgaris 23.7 & & & \\
\hline $\begin{array}{l}\text { Fragilaria } \\
\text { intermedia } 42.6\end{array}$ & Fragilaria capucina 27.7 & $\begin{array}{l}\text { Navicula } \\
\text { cryptocephala } 31.3\end{array}$ & & & \\
\hline $\begin{array}{l}\text { Gomphonema } \\
\text { accuminatum } 40.0\end{array}$ & $\begin{array}{l}\text { Gomphonema } \\
\text { augur } 47.4\end{array}$ & Navicula cryptotenella 38.2 & & & \\
\hline $\begin{array}{l}\text { Gomphonema } \\
\text { parvulum } 37.0\end{array}$ & $\begin{array}{l}\text { Gomphonema } \\
\text { gracile } 18.0\end{array}$ & & & & \\
\hline $\begin{array}{l}\text { Hantzschia } \\
\text { amphioxys } 49.9\end{array}$ & Navicula radiosa 23.9 & & & & \\
\hline Nitzschia scalaris 48.3 & Nitzschia linearis 35.8 & & & & \\
\hline \multicolumn{6}{|l|}{ Pinnularia divergens 31.8} \\
\hline \multicolumn{6}{|l|}{ Pinnularia lata 26.1} \\
\hline \multicolumn{6}{|l|}{ Sellaphora pupula 55.6} \\
\hline \multicolumn{6}{|l|}{ Neidium affine 49.3} \\
\hline \multicolumn{6}{|l|}{ Pinnularia gibba 44.0} \\
\hline \multicolumn{6}{|l|}{ Ulnaria ulna 29.8} \\
\hline \multicolumn{6}{|l|}{ Pinnularia braunii 49.4} \\
\hline \multicolumn{6}{|l|}{ Pinnularia viridis 45.4} \\
\hline $\begin{array}{l}\text { Rhoicosphenia } \\
\text { abbreviata } 43.9\end{array}$ & & & & & \\
\hline
\end{tabular}




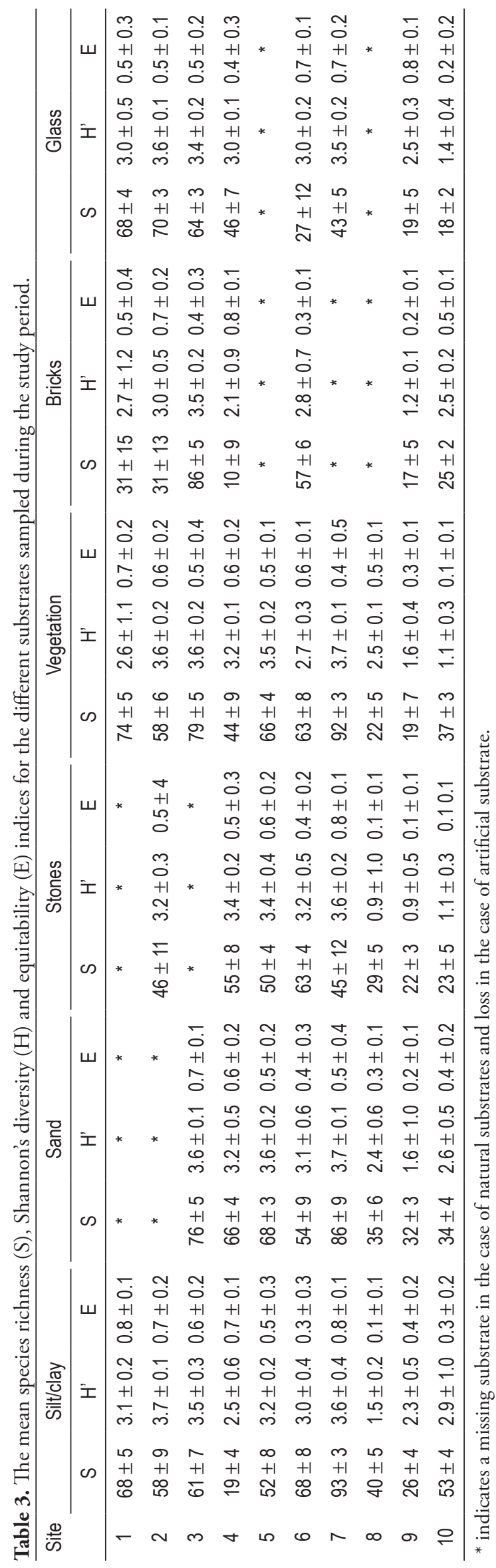



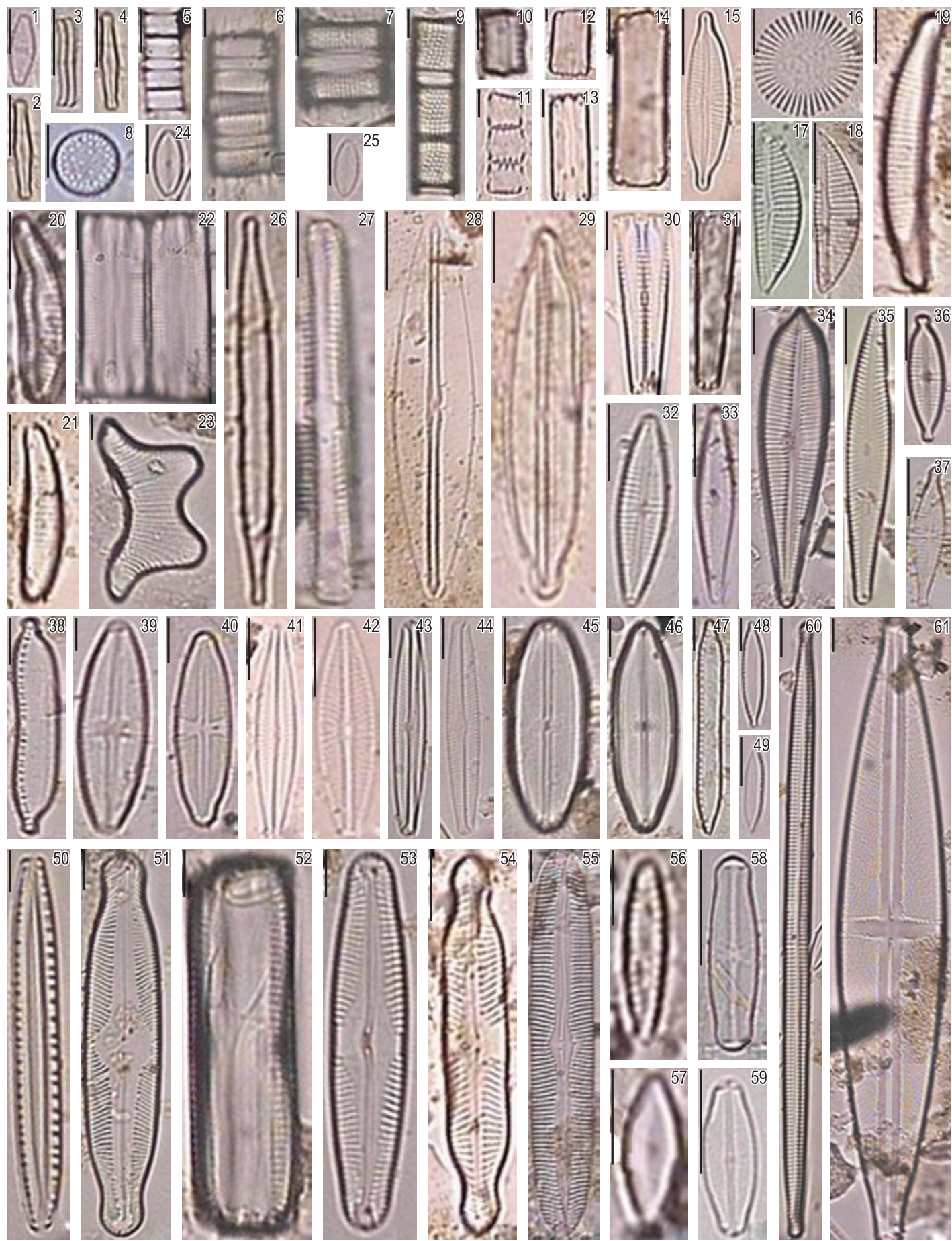

Figure 2. Common diatom species from the Monjolinjo River. Scale $=10 \mu \mathrm{m} .1$ ) Achnanthidium biasolettianum (Kützing) Bukhtiyarova, 2-4) Achnanthidium minutissimum (Kützing) Czarnecki, 5) Aulacoseira alpigena (Grunow) Krammer, 6-7) Aulacoseira agassizii (Hustedt) Simonsen, 8) Aulacoseira distans (Ehrenberg) Simonsen, 9) Aulacoseira ambigua (Grunow) Simonsen, 10-11) Diatoma hiemale (Ehrenberg) Grunow, 12-14) Diatoma vulgare Bory, 15) Cymbopleura naviculiformis, 16) Cyclotella meneghiniana Kützing, 17-18) Encyonema silesiacum (Bleisch) Mann, 19) Eunotia bilunaris (Ehrenberg) Mills, 20-21) Eunotia intermedia (Krasske) Nörpel-Schempp \& Lange-Bert, 22) Eunotia pectinalis (Kiitzing) Rabenhorst, 23) Eunotia papilio (Ehrenberg) Grunow, 24-25) Fallacia monoculata (Hust) Mann, 26) Fragilaria capucina Desmazières, 27) Fragilaria intermedia Grunow, 28) Frustulia saxonica Rabenhorst, 29) Frustulia vulgaris (Thwaites) De Toni, 30-31) Gomphonema accuminatum Ehrenberg, 32-33) Gomphonema angustatum (Kützing) Rabenhorst, 34) Gomphonema augur (Ehrenberg) LangeBertalot, 35) Gomphonema gracile Ehrenberg, 36-37) Gomphonema parvulum (Kützing) Kützing, 38) Hantzschia amphioxys (Ehrenberg) Grunow, 39-40) Luticola goeppertiana (Bleisch) Mann, 41) Navicula cryptocephala (Grunow) Cleve, 42) Navicula cryptotenella Lange-Bertalot, 43-44) Navicula radiosa Kützing, 45) Neidium affine (Ehrenberg) Pfitzer, 46) Neidium ampliatum (Ehrenberg) Krammer, 47) Nitzschia linearis (Agardh) Smith, 48-49) Nitzschia palea (Kützing) Smith, 50) Nitzschia scalaris (Kützing) Grunow, 51) Pinnularia divergens Krammer, 52) Pinnularia lata (Brébisson) Rabenhorst, 53) Pinnularia gibba Ehrenberg, 54) Pinnularia braunii (Grunow) Cleve, 55) Pinnularia viridis (Nitzsch) Ehrenberg, 56) Rhoicosphenia abbreviata (Agardh) Lange-Bertalot, 57) Nupela praecipua (Reichardt) Reichardt, 58-59) Sellaphora pupula (Kützing) Mereschkowsky, 60) Ulnaria ulna (Nitzsch) Compère, 61) Stauroneis phoenicenteron (Nitzsch) Ehrenberg. 
Table 4. Results of Kruskal-Wallis with Mann-Whitney pairwise comparisons of species substrate preferences. Significant differences $(\mathrm{p}<0.05)$ are highlighted

\begin{tabular}{lcccccc}
\hline & Vegetation & Sand & Silt/clay & Stones & Glass & Bricks \\
\hline Vegetation & & $\mathbf{0 . 0 1}$ & $\mathbf{0 . 0 0}$ & 0.03 & 0.18 & 0.12 \\
Sand & 0.16 & & 0.83 & 0.54 & 1.00 & 0.91 \\
Silt & 0.05 & 1.00 & & 0.30 & 0.82 & 0.88 \\
Stones & 0.47 & 1.00 & 1.00 & & 0.86 & 0.82 \\
Glass & 1.00 & 1.00 & 1.00 & 1.00 & & 0.77 \\
Bricks & 1.00 & 1.00 & 1.00 & 1.00 & 1.00 & \\
\hline
\end{tabular}

(Kützing) Rabenhorst, Pinnularia gibba (Ehrenb.) Grunow and Ulnaria ulna (Nitzsch) Compère.

Indicator species analysis showed that common diatom species were not restricted to single substrate. Indicator values ranged from 18.0 to $71.3 \%$ in this study (Table 2). Indicator values can vary from $0 \%$ for a taxon that has the same occurrence and abundance in all the groups of substrates to $100 \%$ for a taxon that is confined to one group of substrate. However, some species tended to prefer certain substrates as indicated by their high indicator values in these preferred substrates. Mean species preference was significantly high (Kruskal-Wallis, $\mathrm{p}<0.05$ ) on vegetation compared to sand, stones and silt/clay (Table 4). No significant difference in mean species preference was observed between natural and artificial substrates (Kruskal-Wallis, $\mathrm{p}>0.05$ ). However more species had highest preference on vegetation (19 species) compared to other substrates i.e. 10, 7, 4, 3 and 2 species for sand, silt/clay, stones, glass and bricks respectively (Table 2 ).

Few species that preferred artificial substrate (glass and bricks) include F. monoculata, N. palea, $G$. angustatum, N. praecipua and L. geoppertiana. These species are commonly reported to be associated with waters of relatively high ionic strength and high conductivity (Round, 1991; Biggs and Kilroy, 2000; Potapova and Charles, 2003; Duong et al., 2006), are known to be resistant to heavy metal pollution (Gold et al., 2003; Morin et al., 2007, 2008a,b; Duong et al., 2008, 2010) and have been frequently recorded in waters with high organic pollution (Sládecék, 1986; Salomoni et al., 2006), eutrophication (Lavoie et al., 2008; Ponader et al., 2007; Kelly and Whitton, 1995), and low dissolved oxygen (Round, 1991; Biggs and Kilroy, 2000; Potapova and Charles, 2003; Duong, 2007). Achnanthidium minutissimum, also commonly considered a disturbance-tolerant species (Stevenson and Bahls, 1999), was often associated with vegetation.
Species belonging to the genera Aulacoseira, Diatoma, Eunotia, Fragilaria, Frustulia, Pinnularia, Navicula, Neidium, Ulnaria, some Gomphonema and Nitzschia species commonly reported to be associated with relatively clean to moderately polluted waters (Round, 1991; Biggs and Kilroy, 2000; Potapova and Charles, 2003; Bicudo and Menezes, 2006, Duong, 2007), thought some of the species are pollution tolerant, were associated with natural substrates i.e. vegetation, sand, silt/clay and stones. Among the natural substrates, the traditionally preferred stones for periphyton sampling (Descy and Coste, 1991; Round, 1991; Pan et al., 1996; Biggs and Kilroy, 2000; Duong et al., 2006; Lowe and Pan, 1996; Kelly et al., 1998) had the least number of species (4; Table 2) associated with them.

\section{Discussion}

\subsection{Community structure in relation to environmental gradients}

Species richness, diversity and equitability differed significantly among sampling sites, tending to be higher in relatively unpolluted compared to polluted sites. As pollution increased, low pollution tolerant species such as A. ambigua and Cymbopleura naviculiformis were replaced by high pollution tolerant species such as $G$. parvulum, $N$. palea, $N$. praecipua, $R$. abbreviata, S. pupula, F. monoculata and L. goeppertiana. The letter group of species has been commonly reported to be associated with waters of relatively high ionic strength and high conductivity (Round, 1991; Biggs and Kilroy, 2000; Potapova and Charles, 2003; Duong et al., 2006), are known to be resistant to heavy metal pollution (Gold et al., 2003; Morin et al., 2007, 2008a, b; Duong et al., 2008, 2010) and have been frequently recorded in waters with high organic pollution (Sladecek, 1986; Salomoni et al., 2006), eutrophication (Lavoie et al., 2008; Ponader et al., 2007; Kelly and Whitton, 1995), and low dissolved oxygen (Round, 1991; Biggs and Kilroy, 2000; 
Potapova and Charles, 2003; Duong, 2007). LangeBertalot (1978) stated that species are indicative of the upper limits of pollution that they can tolerate and not the lower limit. Thus, species that develop well in polluted zones (e.g. G. parvulum, N. palea, $N$. praecipua, $R$. abbreviata, S. pupula, F. monoculata and L. goeppertiana. in this case) may also occur in fairly clean water. Their value as an indicator is their presence in polluted water.

\subsection{Effects of substrates on diatom community structure}

Species richness, diversity and equitability showed no significant difference among the substrates. However, more species tended to prefer vegetation compared to other substrates as indicated by their high indicator values on this substrate. Traditionally stones have been the preferred substrate for sampling during benthic diatom studies (Descy and Coste, 1991; Round, 1991; Pan et al., 1996; Biggs and Kilroy, 2000; Duong et al., 2006; Lowe and Pan, 1996; Kelly et al., 1998). Values of some diatom indices indeed varied with substrate type in Finnish rivers, being highest, for samples collected from vegetation, slightly low for samples from stones, and lowest for samples from soft-sediment samples (Eloranta and Andersson, 1998). However, the statistical significance of these differences was not established. Studies by Porter et al., (1993), Lowe and Pan, (1996) and Kelly et al., (1998) noted that there is no consensus concerning assessment of benthic diatom community structure based on epiphytic and epilithic communities while Soinine and Eloranta (2004) have collected evidence that cautions against it. In this study, significantly more species tended to prefer vegetation compared to stones.

\subsection{Comparison of natural and artificial substrates}

More species had highest indicator values on natural substrate compared to artificial substrate. The floral of artificial substrates is an artificial assemblage selected by physical and chemical properties of the substrate (e.g. texture, chemical composition) and perhaps positioning of substrate in relation to the currents. The smooth surface of glass slides, for example, often results in sloughing of the community (Descy and Coste, 1991).

Each species has specific substrate requirements (Round, 1991) and these requirements in most cases are not met by artificial substrate limiting the number of species that can grow on these substrates. This affects the interpretation of water quality management results as the absence of a particular species on a given site is likely to be mistaken for the effects of the perturbations under study.

Komárek and Sukacová (2004) have shown that introduced artificial substrates are often characterized by diatom communities indicative of more successional processes than water quality. They recommend leaving artificial substrate for a year before sampling to allow the diatom communities to progress from a colonization community to a stable community reflecting environmental conditions and typical of natural communities. This prevents rapid estimation of water quality such as can be obtained within hours of direct sampling of natural substrates. Besides, use of artificial substrate requires apparatus to be fixed in the river and there are often losses, as in our case, and random sampling is not possible (Round, 1991; Descy and Coste, 1991). This further complicates the use of artificial substrate in benthic diatom studies. Sampling of natural substrates is thus highly recommended compared to artificial substrates.

\section{Conclusion}

Substrate differences may affect benthic diatom communities growing on them. Benthic diatoms tend to prefer natural substrates, especially vegetation, compared to artificial substrates, because of the selective nature of the physical and chemical properties of artificial substrates.

\section{Acknowledgements}

This study is made possible by the provision of funds from Third World Academy of Science (TWAS) through Conselho Nacional de Desenvolvimento Científico e Tecnológico (CNPq). I am greatly indebted to my supervisor, Professor José Galizia Tundisi, for his critical remarks on earlier drafts of this work. I also wish to thank the Insttituto Internacional de Ecologia and staff for their support during the course of this study.

\section{References}

APHA, MAH. (ed.). 1998. Standard Methods for the Examination of Water and Waste Water. American Public Health Association, Washington, DC.

BICUDO, CEM. and MENEZES, M. 2006. Gêneros de água de águas continentais do Brazil: chave para identificação e descriçôes. São Carlos: Rima; p. 391-439.

BIGGS, BJF. 1990. Periphyton communities and their environmental gradients in New Zealand Rivers. 
New Zealand Journal of Freshwater Research, vol. 24, p. 367-386.

BIGGS, BJF. 1995. The contribution of flood disturbances, catchment geology and land use to the habitat template of periphyton in stream ecosystems. Freshwater Biology, vol. 33, p. 419-438.

BIGGS, BJF. and KILROY, C. 2000. Stream periphyton monitoring manual. Christchurch: NIWA; 208 p.

BOURRELLY, P. 1981. Les algues d'eau douce: initiation à la systematique. Paris: Société Nouvelle des Editions Boubée; 399 p.

Brasil. Ministério do Planejamento, Orçamento e Gestão. Instituto Brasileiro de Geografia e Estatística IBGE. 2008. Pesquisa nacional de saneamento básico. Available from: <www.ibge.gov.br/home/estatistica/ populacao/>

DELGADO, SM. and SOUZA, MGM. 2007. Diatomoflórula do rio Descoberto-DF e GO, Brazil, Naviculales (Bacillariophyceae): Diploneidineaes e Sellaphorineae. Acta Botanicâ Brazilianse vol. 21, p. 767-776.

DESCY, JP. and COSTE, M. 1991. A test of methods for assessing water quality based on diatoms. Verhandlungen der Internationalen Vereinigung für Theoretische und Angewandte Limnologie, v. 24, p. 2112-2116.

DUFRÊNE, M. and LEGENDRE, P. 1997. Species assemblages and indicator species: the need for a flexible asymmetrical approach. Ecological Monographs, vol. 67, p. 345-366.

DUONG, T., COSTE, M., FEURTET-MAZEL, A., DANG, D., GOLD, C., PARK, Y. and BOUDOU, A. 2006. Impact of Urban Pollution from the Hanoi Area on Benthic Diatom Communities Collected from the Red, Nhue and Tolich Rivers (Vietnam). Hydrobiologia, vol. 563, p. 201-216.

DUONG, TT., FEURTET-MAZAL, A., COSTE, M., DANG, DK. and BOUDOU, A. 2007. Dynamics of diatom colonization processes in some rivers influenced by urban pollution (Hanoi, Vietnam). Ecological Indicators, vol. 7, p. 839-851.

DUONG, TT., MORIN, S., COSTE, M., HERLORY, O., FEURTET-MAZEL, A. and BOUdOU, A. 2010. Experimental toxicity and bioaccumulation of cadmium in freshwater periphytic diatoms in relation with biofilm maturity. Science of The Total environment, vol. 408, p. 552-562.

DUONG, TT., MORIN, S., COSTE, M., HERLORY, O., FEURTET-MAZEL, A. and BOUDOU, A. 2008. Seasonal effects of cadmium accumulation in periphytic diatom communities of freshwater biofilms. Aquatic Toxicology, vol. 90, p. 19-28.

ELORANTA, P. and ANDERSSON, K. 1998. Diatom indices in water quality monitoring of some SouthFinnish rivers. Verhandlungen der Internationalen
Vereinigung für Theoretische und Angewandte Limnologie, vol. 26, p. 1213-1215.

FISHER, J. and DUNBAR, MJ. 2007. Towards a representative periphytic diatom sample. Hydrology and Earth Systems Science, vol. 11, p. 399-407.

FITZPATRICK, FA., WAITE, IR., D'ARCONTE, PJ., MEADOR, MR., MAUPIN, MA. and GURTZ, ME. 1998. Revised methods for characterizing stream habitat in the National Water-Quality Assessment Program: U.S. Geological Survey Water-Resources Investigations Report 98-4052. Raleigh: U.S. Department of the Interior.

GOLD, C., FEURTE-MAZEL, A., COSTE, M. and BOUDOU, A. 2003. Effects of cadmium stress on periphytic diatom communities in indoor artificial streams. Freshwater Biology, vol. 48, p. 316-328.

GOLTERMAN, HL., CLYMO, RS. and OHNSTAD, MAM. 1978. Methods for Physical and Chemical Analysis of Fresh Waters. Oxford: Blackwell Scientific Publication. 213 p. IBP Handbook, no. 8

HAMMER, O., HARPER, DAT. and RYAN, PD. PAST - PAlacontological Statistics. Version 1.90. Available from: <http://folk.uio.no/ohammer/past. 2009>.

JONGMAN, RHG., TER BRAAK, CJF. and VAN TONGEREN, OFR. 1987. Data analysis in community and landscape ecology. Den Haag: Pudoc Wageningen.

JÜTTNER, I., ROTHFRITZ, H. and ORMEROD, SJ. 1996. Diatoms as indicators of river quality in the Nepalese Middle Hills with consideration of the effects of habitat-specific sampling. Freshwater Biology, vol. 36, p. 475-486.

KELLY, MG. and WHITTON, BA. 1995. The trophic diatom index: a new index for monitoring eutrophication in rivers. Journal of Applied Phycology, vol. 7, p. 433-444.

KELly, MG., CAZAUBON, A., CORING, E., DELL'UOMO, A., ECTOR, L., GOLDSMITH, B., GUASCH, H., HÜRLIMANN, J., JARLMAN, A., KAWECKA, B., KWADRANS, J., LAUGASTE, R., LINDSTROM, E.A., LEITAO, M., MARVAN, P., PADISÁK, J., PIPP, E., PRYGIEL, J., ROTT, E., SABATER, S., VAN DAM, H. and VIZINET, J. 1998. Recommendations for the routine sampling of diatoms for water quality assessments in Europe. Journal of Applied Phycology, vol. 10, p. 215-224.

KITNER, M. and POULÍ-ČKOVÁ, A. 2003. Littoral diatoms as indicators for the eutrophication of shallow lakes. Hydrobiologia, vol. 506-509, p. 519524.

KOMÁREK, O. and SUKACOVÁ, K. 2004. The use of artificial substrate in different growth conditions. Ekologia, Bratilsava, vol. 23, p. 192-206.

LANGE-BERTALOT, $\mathrm{H}$. Pollution tolerance of diatoms as criteria for water quality estimation. 1979. Nova Hedwigia, vol. 64, p. 283-304. 
LAVOIE, I., CAMPEAU, S., DARCHAMBEAU, F., CABANA, G. and DILLON, PJ. 2008. Are diatoms good integrators of temporary variability in stream water quality? Freshwater Biolology, vol. 53, p. 827-841.

LOBO, EA., CALLEGARO, VL. and BENDER, P. 2002. Utilização de algas diatomáceas epilíticas como indicadoras da qualidade da água em rios e arroios da Região Hidrográfica do Guaíba, RS, Brasil. Santa Cruz do Sul: EDUNISC.

LOBO, EA., CALLEGARO, VL., HERMANY, G., BES, D., WETZEL, CE. and OLIVEIRA, MA. 2004. Use of epilithic diatoms as bioindicator from lotic systems in southern Brazil, with special emphasis on eutrophication. Acta Limnologica Brasiliensia, vol. 16, p. 25-40.

LOWE, RL. and PAN, Y. 1996. Benthic algal communities as biological indicators. In STEVENSON, RJ., BOTHWELL, ML., and LOWE, RL. (eds). Algal Ecology: freshwater Benthic Ecosystems. San Diego: Academic Press. p. 705-739.

METZELTIN, D. and LANGE-BERTALOT, H. 2007. Tropical Diatoms of South America II. Iconographia Diatomologica, vol. 18, p. 1-877.

METZELTIN, D., LANGE-BERTALOT, H. and GARCÍA-RODRÍGUEZ, F. 2005. Diatoms of Uruguay. Iconographia Diatomologica, vol. 15, p. 1-736.

MORIN, S., DUONG, TT., DABRIN, A., COYNEL, A., HERLORY, O., BAUDRIMONT, M., DELMAS, F., DURRIEU, G., SCHÄFER, J., WINTERTON, P., BLANC, G. and COSTE, M. 2008a. Longterm survey of heavy-metal pollution, biofilm contamination and diatom community structure in the Riou Mort watershed, South-West France. Environmental Pollution, vol. 151, p. 532-542.

MORIN, S., DUONG, TT., OLIVIER, H., FEURTETMAZEL, A. and COSTE, M. 2008b. Cadmium toxicity and bioaccumulation in freshwater biofilms. Archive Environmental Contamination and Toxicology, vol. 54, p. 173-186.

MORIN, S., VIVAS-NOGUES, M., DUONG, TT., BOUDOU, A., COSTE, M. and DELMAS, F. 2007. Dynamics of benthic diatom colonization in cadmium/zinc-polluted river (Riou-Mort, France). Fundamental of Applied Limnology, vol. 168, p. 179-187.

MOURA, AN., BITTENCOURT-OLIVEIRA, MC. and NASCIMENTO, EC. 2007. Benthic Bacillariophyta of the Paripe River estuary in Pernambuco state, Brazil. Brazilian. Journal of Biology, vol. 67, p. 393-401.

OLIVEIRA, MA., TORGAN, LC., LOBO, EA. and SCHARZBOLD, A. 2001. Association of periphytic diatom species of artificial substrate in lotic environments in the Arroio Sampaio basin, RS,
Brazil: relationships with abiotic variables. Brazilian Journal of Biology, vol. 6, p. 523-540.

PAN, Y., STEVENSON, RJ., HILL, BH., HERLIHY, AT. and COLLINS, GB. 1996. Using diatoms as indicators of ecological conditions in lotic systems: a regional assessment. Journal of North American Bethological Society, vol. 15, p. 481-495.

PAPPAS, JL. and STOERMER, EFF. 1996. Quantitative method for determining a representative algal sample count. Journal of Phycology, vol. 32, p. 693-696.

PATRICK, R. and HENDRICKSON, J. 1993. Factors to consider in interpreting diatom changes. Nova Hedwigia Beihelf, vol. 106, p. 361-377.

PLATTS, WS., MEGAHAN, WF. and MINSHALL, WG. 1983. Methods for evaluating stream, riparian, and biotic conditions. General Technical Report INT-138, USDA Forest Service, Rocky Mountain Research Station. Ogden: University of Texas. 81 p.

PONADER, K. C, CHARLES, DF. and BELTON, TJ. Diatom-based TP and TN inference models and indices for monitoring nutrient enrichment of New Jersey streams. Ecological Indicators, 2007, vol. 7, p. 79-93.

PORTER, SD., CUFFNEY, TF., GURTZ, ME. and MEADOR, MR. 1993. Methods for collecting algal samples as part of the National Water-Quality Assessment Program: U.S. Geological Survey OpenFile Report 93-409. US Geological Survey, Raleigh, North Carolina. Available from: <http://water.usgs. gov/nawqa/protocols/OFR-93-409>.

POTAPOVA, M. and CHARLES, DF. 2003. Distribution of benthic diatoms in U.S. rivers in relation to conductivity and ionic composition. Freshwater Biology, vol. 48, p. 1311-1328.

POTAPOVA, M. and CHARLES, DF. 2005. Choice of substrate in algae-based water quality assessment. Journal of North American Bethological Society, vol. 24, p. 415-427.

ROTT, E., DUTHIE, HC. and PIPP, E. 1998. Monitoring organic pollution and eutrophication in the Grand River, Ontario, by means of diatoms. Canadian Journal of Aquatic Science, vol. 55, p. 1443-1453.

ROUND, FE. 1991. Diatoms in river water-monitoring studies. Journal of Applied Phycology, vol. 3, p. 129-145.

SALOMONI, SE., ROCHA, O., CALLEGARO, VL. and LOBO, EA. 2006. Eplithic diatoms as indicators of water quality in the Gravataí river, Rio Grande do Sul, Brazil. Hydrobiologia, vol. 559, p. 233-246.

SHANNON, CE. 1948. A mathematical theory of communication. Bell System Technical Journal, vol. 27, p. $379-423$

SLÁDECÉK, V. 1986. Diatoms as indicators of organic pollution. Acta Hydrochimical Hydrobiology, vol. 14, p. 555-566. 
SOARES, MCS., SOPHIA, MG. and HUSZAR, VLM. 2007. Phytoplankton flora of two rivers in Southern Brazil-Paraibuna and Pomba Rivers, Minas Gerais. Revista Brasileira de Botanica, vol. 30, p. 433-450.

SOININE, J. and ELORANTA, P. 2004. Seasonal persistence and stability of diatom communities in rivers: are there habitat specific differences? European Journal of Phycology, vol. 39, p. 153-160.

SOUZA, M.G.M. 2002. Variação da comunidade de diatomáceas epiliticas ao longo de um rio impactado no município de São Carlos - SP e sua relação com variáveis fiscas e químicas. Universidade Federal de Sáo Carlos, São Carlos. [Tese de Doutorado em Ciências Biológicas].

SOUZA, MGM. and SENNA, PAC. 2009. Diatomáceas epilíticas da subordem Sellaphorineae do rio do Monjolinho, São Carlos, SP, Brasil. Acta Botânica Brasílica, vol. 23, p. 618-629.
STEVENSON, RJ. and BAHLS, LL. 1999. Periphyton protocols. In BARBOUR, MT., GERRITSEN, J., SNYDER, BD. AND STRIBLING, JB. Rapid bioassessment protocols for use in streams and wadeable rivers: periphyton, benthic macroinvertebrates, and fish. $2^{\circ}$ ed. Washington, DC.: Office of Water, US Environmental Protection Agency.

VALDERRAMA, JC. 1981. The simultaneous analysis of total nitrogen and total phosphorus in natural water. Marine Chemistry, vol. 10, p. 102-122.

ZALOCAR DE DAMITROVIC, Y., POI DE NEIFF, ASG. and CASCO, SL. 2007. Abundante and diversity of phytoplankton in the Paraná River (Argentina) $220 \mathrm{~km}$ downstream of the Yacyretá reservoir. Brazilian Journal of Biology, vol. 67, p. 53-63.

Received: 12 January 2010 Accepted: 14 June 2010 